\title{
Comment on "Ultra low frequency (ULF) electromagnetic anomalies associated with large earthquakes in Java Island, Indonesia by using wavelet transform and detrended fluctuation analysis", by Febriani et al. (2014)
}

\author{
F. Masci and J. N. Thomas \\ Correspondence to: F. Masci (fabrizio.masci@ingv.it)
}

The copyright of individual parts of the supplement might differ from the CC-BY 3.0 licence. 


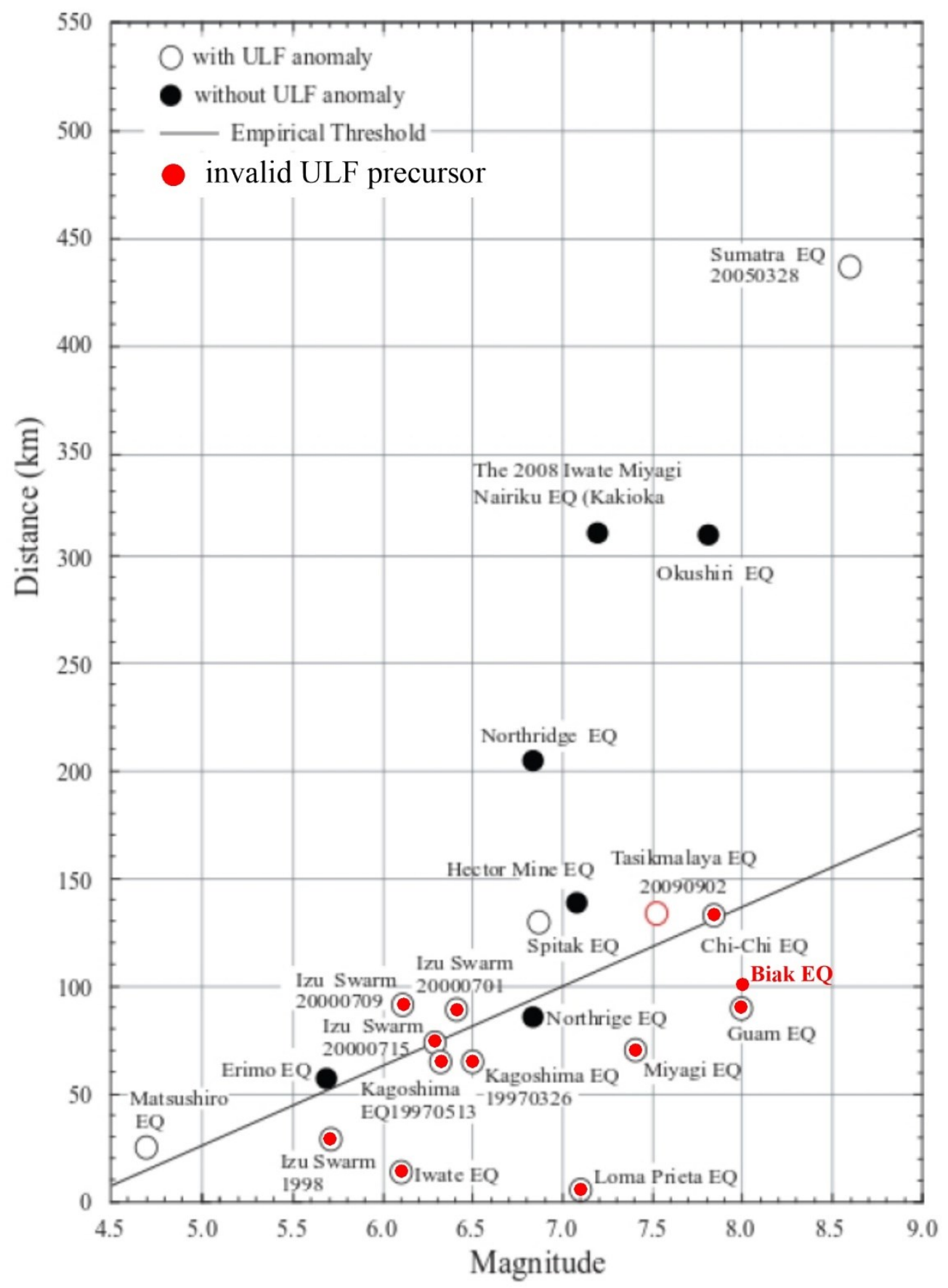

Figure S1. The black continuous line indicates the empirical relationship $(R=40 M-180)$ between the earthquake magnitude $\mathrm{M}$ and the distance $\mathrm{R}$ from the epicenter of the ULF station where the anomaly was observed (see Febriani et al., 2014, Fig. 10). We have included the Biak earthquake as in the original view by Hattori et al. (2004). Note that the relationship was derived using invalid ULF precursors (see Table S2).

\section{References}

Hattori, K., Takahashi I., Yoshino, C., Isezaki N., Iwasaki H., Harada M., Kawabata K., Kopytenko E., Kopytenko Y., Maltsev P., Korepanov V., Molchanov O., Hayakawa M., Noda Y., Nagao T., and S. Uyeda: ULF geomagnetic field measurements in Japan and some recent results associated with Iwateken Nairiku Hokubu earthquake in 1998, Phys. Chem. Earth, 29, 481-494, doi:10.1016/j.pce.2003.09.019, 2004. 
Table S1. Papers cited by Febriani et al. (2014) (and corresponding reviews) that have reported invalid ULF magnetic precursors.

\begin{tabular}{|c|c|c|}
\hline Papers & Earthquake & Reviews \\
\hline Akinaga et al., 2001. & 1999 Chi-Chi earthquake & Masci, F., 2011a, doi:10.1016/j.pepi.2011.05.001 \\
\hline Fraser-Smith et al., 1990. & 1989 Loma Prieta & $\begin{array}{l}\text { Campbell, 2009, doi:10.1029/2008JA013932* } \\
\text { Thomas et al., 2009a, doi:10.1016/j.pepi.2008.11.014 }\end{array}$ \\
\hline Hattori, 2004. & $\begin{array}{l}1998 \text { Iwateken Nairiku Hokubu } \\
1997 \text { Kagoshimaken-Hokuseibu }\end{array}$ & Masci, F., 2011a, doi:10.1016/j.pepi.2011.05.001 \\
\hline Hattori et al., 2002. & 1997 Kagoshimaken-Hokuseibu & Masci, F., 2011a, doi:10.1016/j.pepi.2011.05.001 \\
\hline Hattori et al., 2004a. & 1998 Iwateken Nairiku Hokubu & Masci, F., 2011a, doi:10.1016/j.pepi.2011.05.001 \\
\hline Hattori et al., 2004b. & $2000 \mathrm{Izu}$ & Masci, F., 2011b, doi:10.5194/nhess-11-2193-2011. \\
\hline Hayakawa et al., 2008. & 1993 Guam & $\begin{array}{l}\text { Masci, F., 2010, doi:10.1029/2010JA015311. } \\
\text { Masci, F., 2013, doi:10.5194/nhess-13-187-2013. }\end{array}$ \\
\hline Hayakawa et al., 1996. & 1993 Guam & $\begin{array}{l}\text { Masci, F., 2011a, doi:10.1016/j.pepi.2011.05.001 } \\
\text { Thomas et al . 2009b, doi:1029/2009GL039020 }\end{array}$ \\
\hline Hayakawa et al., 2007. & 1997 Kagoshimaken-Hokuseibu & Masci, F., 2011a, doi:10.1016/j.pepi.2011.05.001 \\
\hline Hirano and Hattori, 2011. & 2008 Iwate-Miyagi Nairiku & Masci, F., 2012, doi:10.1016/j.jseaes.2012.06.009. \\
\hline Ida and Hayakawa, 2006. & 1993 Guam & Masci, F., 2010, doi:10.1029/2010JA015311. \\
\hline Ida et al., 2006. & 1993 Guam & Masci, F., 2013, doi:10.5194/nhess-13-187-2013 \\
\hline
\end{tabular}

* Reply: Fraser-Smith et al., (2011), Comment on "Natural magnetic disturbance fields, not precursors, preceding the Loma Prieta earthquake" by Wallace H. Campbell, J. Geophys. Res., 116, A08228, doi:10.1029/2010JA016379. 
Table S2. Papers where alleged ULF precursors highlighted in Figure S1 by red dots have been denied.

\section{Earthquake}

Loma Prieta EQ 17-101989

Guam EQ 08-08-1993

Biak EQ 17-02-1996

Kagoshima EQs 03-26-1997, 05-13-1997

Iwate EQ 03-09-1998 Izu Swarm April-May 1998

Chi-Chi EQ 21-09-1999

Izu Swarm June-August 2000

Miyagi EQ 13-06-2008

\section{Reviews}

Campbell, W. H. (2009), Natural magnetic disturbance fields, not precursors, preceding the Loma Prieta earthquake, J. Geophys. Res., 114, A05307, doi:10.1029/2008JA013932.*

Thomas, J. N., Love, J. J, Johnston, M. J. S.: On the reported magnetic precursor of the 1989 Loma Prieta earthquakes, Phys. Earth Planet. Int., 173, 207-215, doi:10.1016/j.pepi.2008.11.014, 2009.

Thomas, J. N., Love, J. J, Johnston, M. J. S., Yumoto, K.: On the reported magnetic precursor of the 1993 Guam earthquake, Geophys. Res. Lett., 36, L16301, doi:10.1029/2009GL039020, 2009.

Masci, F.: On claimed ULF seismogenic fractal signatures in the geomagnetic field, J. Geophys. Res., A10236,115, doi:10.1029/2010JA015311, 2010.

Masci, F.: On the seismogenic increase of the ratio of the ULF geomagnetic field components. Phys. Earth Planet. Int., 187, 19-32, doi:10.1016/j.pepi.2011.05.001, 2011.

Masci, F.: Brief communication "On the recent reaffirmation of ULF magnetic earthquakes precursors", Nat. Hazards Earth Syst. Sci., 11, 2193-2198, doi:10.5194/nhess-11-2193-2011, 2011.

Masci, F.: On the multi-fractal characteristics of the ULF geomagnetic field before the 1993 Guam earthquake, Nat. Hazards Earth Syst. Sci., 13, 187-191, doi:10.5194/nhess-13-187-2013, 2013.

Masci, F.: On claimed ULF seismogenic fractal signatures in the geomagnetic field, J. Geophys. Res., A10236,115, doi:10.1029/2010JA015311, 2010.

Masci, F.: 2011, On the seismogenic increase of the ratio of the ULF geomagnetic field components. Phys. Earth Planet. Int., 187, 19-32, doi:10.1016/j.pepi.2011.05.001, 2011.

Masci, F.: 2011, On the seismogenic increase of the ratio of the ULF geomagnetic field components. Phys. Earth Planet. Int., 187, 19-32, doi:10.1016/j.pepi.2011.05.001, 2011.

Masci, F.: 2011, On the seismogenic increase of the ratio of the ULF geomagnetic field components. Phys. Earth Planet. Int., 187, 19-32, doi:10.1016/j.pepi.2011.05.001, 2011

Masci, F.: 2011, On the seismogenic increase of the ratio of the ULF geomagnetic field components. Phys. Earth Planet. Int., 187, 19-32, doi:10.1016/j.pepi.2011.05.001, 2011.

Masci, F.: 2011, On the seismogenic increase of the ratio of the ULF geomagnetic field components. Phys. Earth Planet. Int., 187, 19-32, doi:10.1016/j.pepi.2011.05.001, 2011.

Masci, F.: 2011, On the seismogenic increase of the ratio of the ULF geomagnetic field components. Phys. Earth Planet. Int., 187, 19-32, doi:10.1016/j.pepi.2011.05.001, 2011.

Masci, F., and J.N., Thomas: On the relation between the seismic activity and the Hurst exponent of the geomagnetic field at the time of the 2000 Izu swarm, Nat. Hazards Earth Syst. Sci., doi:10.5194/nhess-13-2189-2013, 2013 .

Masci, F: On the ULF magnetic ratio increase before the 2008 Iwate-Miyagi Nairiku earthquake by Hirano and Hattori (2011), J. Asian Earth Sci., 56, 258-262, doi:10.1016/j.jseaes.2012.06.009, 2012.

* Reply: Fraser-Smith et al., (2011), Comment on "Natural magnetic disturbance fields, not precursors, preceding the Loma Prieta earthquake" by Wallace H. Campbell, J. Geophys. Res., 116, A08228, doi:10.1029/2010JA016379. 